\title{
Efektivitas Model Pembelajaran Make A Match dalam Meningkatkan Kemampuan Membaca Permulaan bagi Anak Disleksia di Sekolah Dasar Penyelenggara Pendidikan Inklusif
}

\author{
Johandri Taufan ${ }^{1}$, Ardisal $^{2}$, Konza Yola Konitah ${ }^{3}$ \\ Universitas Negeri Padang, Sumatera Barat, Indonesia ${ }^{1,2,3}$ \\ E-mail: johandri.taufan@fip.unp.ac.id ${ }^{1} \underline{\text { ardisalarnev@ @ip.unp.ac.id }{ }^{2}} \underline{\text { konzayolakonitah@yahoo.co.id }{ }^{3}}$
}

\begin{abstract}
Abstrak
Artikel ini membahas tentang peningkatan kemampuan membaca permulaan pada anak disleksia dengan menggunaka model pembelajaran make a match. Penelitian ini bertujuan untuk membuktikan apakah model pembelajaran make a match efektif meningkatkan kemampuan membaca permulaan. Penelitian ini menggunakan single subject research dengan desain A-B-A dan analisis data penelitian menggunakan teknik analisis visual grafik. Analisis data menunjukkan baseline (A1) kemampuan membaca permulaan dilakukan selama 4 hari dengan mean 30 dan kecendrungan arah tetap dan perubahan data tetap dilanjutkan dengan intervensi selama 5 hari dengan mean $96 \%$. Kecendrungan arah meningkat dan perubahan data meningkat selanjutnya peneliti melakukan baseline (A2) dilakukan selama 4 hari dengan mean $100 \%$ dan kecendrungan arah tetap dan perubahan data tetap serta overlape data yang memiliki persentase rendah. Hasil dari penelitian ini adalah bahwa metode pembelajaran make a match efektif meningkatkan kemampuan membaca permulaan bagi anak disleksia kelas 2 di sekolah dasar.
\end{abstract}

Kata kunci: membaca permulaan, make a match, disleksia

\section{Abstract}

This article discusses the improvement of early reading skills in dyslexic children with a model using make a match learning. This study aims to prove whether an effective learning model improves pre-reading skills. The research methodology used a single subject study with A-B-A design and data analysis using visual chart analysis techniques. Data analysis showed baseline (A1) reading ability at baseline was carried out for 4 days with a mean of 30 and a constant trend and changes in data interacted with the intervention for 5 days with a mean of $96 \%$. The trend in the direction of increasing and changing data increased. Researchers carried out the baseline (A2) carried out for 4 days with a mean of 100\% and the direction of the trend was fixed and changes in data were fixed and data overlapped which had a low proportion. Dyslexia that the learning method makes an effective match in improving the beginning reading skills for grade 2 dyslexic children in Public Elementary Schools in Padang City.

Keywords: early reading, make a match, dyslexia

Copyright (c) 2020 Johandri Taufan, Ardisal, Konza Yola Konitah

$\triangle$ Corresponding author

Address : Limau Manis Padang

Email : johandri.taufan@ fip.unp.ac.id

ISSN 2580-3735 (Media Cetak)

Phone : 082284046262

ISSN 2580-1147 (Media Online)

DOI: https://doi.org/10.31004/basicedu.v4i4.521 
1150 Efektivitas Model Pembelajaran Make A Match dalam Meningkatkan Kemampuan Membaca Permulaan bagi Anak Disleksia di Sekolah Dasar Penyelenggara Pendidikan Inklusif - Johandri Taufan, Ardisal, Konza Yola Konitah

DOI: https://doi.org/10.31004/basicedu.v4i4.521

\section{PENDAHULUAN}

Membaca merupakan suatu kegiatan bagi pembaca untuk memperoleh pesan dari isi tulisan yang ada pada sekelompok kumpulan huruf yang membentuk suku kata, kelompok kata, kalimat, paragraf dan wacana dengan memahami makna yang disampaikan oleh penulis agar dapat menambah pengetahuan dan wawasan. (Djamarah \& Bahri, 2008) membaca adalah "kegiatan melihat serta memahami isi dari yang tertulis dengan melisankan atau tanya dalam hati”.

Penyelenggaraan pendidikan bertujuan untuk mencerdaskan kehidupan bangsa dan menyiapkan peserta didik menjadi terampil. Melalui kegiatan bimbingan dan pengajaran, siswa di didik untuk mengembangkan potensi yang ada dan yang dimiliki. Penyelenggaraan pendidikan menegaskan bahwa setiap warga negara memiliki hak yang sama untuk mendapatkan kecerdasan melalui pendidikan juga pengajaran dan termasuk anak dengan berkebutuhan khusus. Dalam pendidikan, membaca juga hal yang sangat penting, karena apabila peserta didik dapat membaca dengan baik maka peserta didik dapat mengikuti proses belajar mengajar dengan baik pula.

Anak berkebutuhan khusus perlu mendapatkan pendidikan yang sama dengan anak lainnya agar mereka bisa mendapatkan kemudahan dalam berkembang di dalam kehidupan bermasyarakat. Untuk itu mereka harus dikembangkan potensinya, dengan mengupayakan memberikan bantuan khusus yang maksimal pada mereka sehingga mereka dapat memperoleh informasi yang sama dengan anak lainnya. Khususnya bagi anak disleksia agar mereka tidak tertinggal dalam memperoleh infomasi. Informasi tersebut diperoleh sebagian dari proses membaca, jika dalam membaca anak mengalami masalah maka akan sulit menerima informasi yang utuh sebagaimana mestinya. Setiap kehidupan melibatkan kegiatan membaca karena membaca sangat penting dalam kehidupan maka dari itu pemerintah memasukkan membaca kedalam kurikulum pendidikan, mulai dari tingkat dasar sampai jenjang pendidikan yang tinggi.

Membaca memiliki tujuan untuk mengetahui informasi yang ada dalam bentuk tertulis. Tahap yang paling dasar dalam membaca adalah mampu membaca permulaan. Membaca permulaan adalah tahap awal seseorang dari proses membaca yang harus dipelajari dan dikuasi yakni dari huruf, suku kata, kata dan kalimat. Tarigan dalam (Dalman, 2014) membaca permulaan cakupannya pengenalan bentuk huruf, pengenalan unsur-unsur linguistik (ilmu bahasa), pengenalan hubungan pola ejaan dengan bunyi, juga kecepatan membaca bertaraf lambat.

Pada anak di sekolah dasar (SD) khususnya, harus menguasai keterampilan dalam membaca, agar mereka mampu mengikuti proses kegiatan belajar selanjutnya. Berdasarkan Kompetensi Dasar bahasa Indonesia kelas I, siswa dituntut untuk mengenal dan menjelaskan kosakata yang berkaitan dengan peristiwa siang dan malam melalui teks pendek. Dan salah satu Indikatornya yakni membaca dan menulis kosa kata-kosa kata kegiatan malam hari dengan benar. Pada kelas I 
1151 Efektivitas Model Pembelajaran Make A Match dalam Meningkatkan Kemampuan Membaca Permulaan bagi Anak Disleksia di Sekolah Dasar Penyelenggara Pendidikan Inklusif - Johandri Taufan, Ardisal, Konza Yola Konitah

DOI: https://doi.org/10.31004/basicedu.v4i4.521

SD saja anak sudah diminta untuk membaca kata, apalagi untuk anak kelas $2 \mathrm{SD}$, diharuskan untuk memahami bacaan.

Berdasarkan studi pendahuluan ditemukan seorang siswa perempuan mengalami kesulitan dalam hal membaca yang berumur 8 tahun yang tengah belajar di sekolah SDN Penyelenggara Pendidikan Inklusif di Kota Padang. Peneliti melakukan assessment kepada siswa, yang mana siswa diminta untuk membaca huruf abjad dari A$\mathrm{Z}$, dari beberapa huruf yang dibaca siswa, huruf $\mathrm{F}, \mathrm{Q}, \mathrm{V}, \mathrm{X}$ salah dalam penyebutannya, lalu siswa diminta untuk membaca kata pada teks yang disediakan penulis, anak banyak mengalami pengurangan, penambahan, penggantian huruf dalam kata. Jika dilihat dari hasil nilai rapor siswa, sebelumnya pada rapor kelas 1 semester 1 pada pelajaran Bahasa Indonesia terdapat KKM 70 dan anak mendapatkan nilai 64. Dan pada semester 2 anak mendapatkan nilai 75 , guru di sekolah tersebut mengatakan jika di sekolah ini banyak siswanya yang dinaik-kelaskan dengan cara diberi nilai tambahan pada rapor atau dinaikkan dengan nilai yang sudah diubah dari nilai aslinya.

Dilihat dari hasil assessment diatas menunjukkan bahwa, anak mengalami kesulitan dalam hal membaca. Biasanya anak yang mengalami kesulitan dalam hal membaca disebut anak disleksia. Anak disleksia merupakan anak yang berkecerdasan normal, namun mengalami kesulitan dalam hal membaca, sehingga dalam proses pembelajarannya sering mengalami ketinggalan dari temannya di sekolah. Menurut (Jamaris, 2009) disleksia merupakan "kondisi yang berkaitan dengan kemampuan membaca yang sangat tidak memuaskan". Individu yang mengalami disleksia memiliki IQ normal bahkan diatas normal, akan tetapi memiliki kemampuan membaca 1 atau 11/2 tingkat di bawah kemampuan IQ-nya. Berdasarkan hasil pengamatan dan wawancara peneliti dengan guru, selama ini guru mengajarkan membaca kepada siswa dengan metode ceramah dan latihan seperti kata yang guru sebutkan dan tuliskan di papan tulis, siswa di suruh untuk menyebutkan dan menuliskannya di buku masing-masing.

Berdasarkan hasil pengamatan dan permasalahan yang ditemukan di lapangan, peneliti tertarik untuk mengangkat masalah ini untuk diteliti. Oleh sebab itu, berdasarkan dari hal tersebut di atas perlunya penangan yang diberikan kepada siswa secara optimal. Salah satunya dengan cara meningkatkan kemampuan membaca permulaan bagi anak disleksia melalui metode pembelajaran Make A Match. Adapun pendekatan melalui metode Make A Match yaitu suatu cara yang digunakan guru dalam pembelajaran dengan meminta siswa untuk mencari pasangan kartu jawaban dengan kartu pertanyaan. Menurut Curran (dalam Pathanah, 2015) metode Make A Match (mencari pasangan) adalah "suatu teknik mencari pasangan kartu yang menyenangkan pada siswa, siswa disuruh mencari pasangan dari kartu yang mereka pegang". Alasan peneliti menggunakan metode Make A Match ini karena dapat dilakukan kapan saja dan dimana saja, asalkan kartu - kartu tersebut ada, dan metode ini juga sangat menyenangkan membuat siswa aktif dalam 
1152 Efektivitas Model Pembelajaran Make A Match dalam Meningkatkan Kemampuan Membaca Permulaan bagi Anak Disleksia di Sekolah Dasar Penyelenggara Pendidikan Inklusif - Johandri Taufan, Ardisal, Konza Yola Konitah

DOI: https://doi.org/10.31004/basicedu.v4i4.521

mencari serta mencocokkan kartu jawaban dengan kartu soal. Jika pembelajaran dirancang dengan make a match menyenangkan, dan adanya media kartu bergambar dapat menyampaikan pesan instruksional maka hal ini memperkuat keterampilan sosial siswa, menciptakan suasana belajar gembira, membuat siswa termotivasi dalam belajar dan hasil belajar yang diinginkan dapat terwujud (Fatimah, 2017). Selain itu menurut (Deschuri et al., 2016) teknik make a match ini mampu menciptakan kondisi kelas yang interaktif, efektif sebagai sarana untuk melatih keberanian siswa, serta mampu menghilangkan kebosanan siswa ketika pembelajaran berlangsung. Menurut (Nurhidayah et al., 2017) sebelum menerapkan model pembelajaran make a match ada beberapa persiapan yang harus dilakukan oleh guru, diantaranya menyiapkan daftar pertanyaan yang sesuai dengan materi yangakan diajarkan, membuat daftar kunci jawaban yang sesuai dengan pertanyaan-pertanyaan yang sudah disiapkan sebelumnya, membuat petunjuk kartu yang akan membantu siswa, membuat aturan permainan yang berisi penghargaan bagi siswa yang berhasil mendapatkan pasangan kartunya sebelum waktu habis, serta menyiapkan catatan untuk mencatat nama-nama siswa yang berhasil.

Adapun rumusan masalah penelitian dalam penelitan ini adalah "Efektivitas Model Pembelajaran Make A Match dalam Meningkatkan Kemampuan Membaca Permulaan bagi Anak Disleksia di Sekolah Dasar Penyelenggara Pendidikan Inklusif".

\section{METODE}

Penelitian ini merupakan jenis penelitian eksperimen dalam bentuk Single Subject Research (SSR). Penelitian eksperimen merupakan suatu kegiatan percobaan yang dilakukan untuk melihat ada tidaknya pengaruh intervensi/perlakuan terhadap perubahan perilaku sasaran (target behavior). Menurut (Sunanto, 2005) penelitian eksperimen bertujuan untuk mengetahui hubungan fungsional atau hubungan sebab akibat antara variabel terikat dengan variabel bebas. Penelitian yang dilakukan ini menggunakan desain A-B-A, dilakukan dengan tiga tahapan.

Pada tahapan pertama dilakukan dengan cara melihat kemampuan awal anak dalam melakukan membaca kata benda yakni membaca permulaan disebut juga dengan nama target behavior pada kondisi awal sebelum diberikan intervensi (B) atau baseline (A1), pada tahap kedua yaitu diberikan perlakuan atau intervensi (B) dengan memberikan metode pembelajaran Make A Match, dan pada tahap ketiga ini melihat kemampuan kemampuan siswa tanpa diberikan perlakuan baseline (A2). Pengamatan dilakukan pada anak disleksia. Variabel dalam penelitian ini ada dua variabel yaitu variabel bebas dan variabel terikat. Adapun variabel terikat dalam penelitian ini yaitu kemampuan membaca permulaan untuk variabel bebasnya adalah metode pembelajaran Make A Match.

Pencatatan data dilakukan peneliti dengan menggunakan instrumen tes aspek-aspek dalam membaca permulaan, pencatatan yang dipilih dalam pencatatan kemampuan membaca 
1153 Efektivitas Model Pembelajaran Make A Match dalam Meningkatkan Kemampuan Membaca Permulaan bagi Anak Disleksia di Sekolah Dasar Penyelenggara Pendidikan Inklusif - Johandri Taufan, Ardisal, Konza Yola Konitah

DOI: https://doi.org/10.31004/basicedu.v4i4.521

permulaan dengan persentase. Alat pengumpulan data dalam penelitian ini menggunakan format pengumpulan data pada kondisi baseline (A1), intervensi (B), dan baseline (A2).

\section{Analisis Dalam Kondisi}

Analisis dalam kondisi adalah menganalisis perubahan data dalam satu kondisi misalnya kondisi baseline atau intervensi sedangkan komponen yang dimaksud dalam penelitian ini adalah data dalam grafik masing-masing kondisi, dengan langkah-langkah sebagai berikut:

a. Menentukan panjang kondisi

Menurut (Sunanto, 2005), panjang kondisi adalah banyaknya data dalam komponen tersebut. Data dalam kondisi baseline sebelum diberkan intervensi (A) dan kondisi intervensi (B) dikumpulkan sampai data menunjukkan stabilitas dan arah yang jelas.

b. Menentukan kecendrungan arah Menurut (Sunanto, 2005), kecenderungan arah digambarkan oleh garis lurus yang melintasi semua data dalam suatu kondisi dimana banyaknya data yang berada diatas dan dibawah garis tersebut sama banyak. Ada tiga macam kecendrungan arah grafik yaitu meningkat, mendatar dan menurun. Untuk membuat garis ini dapat ditempuh dengan dua metode : pertama metode tangan bebas (freehand) dan metode belah tangan (split-middle). Metode freehand adalah pengamatan yang dilakukan secara langsung terhadap data point pada suatu kondisi kemudian menarik garis lurus yang membagi data poin menjadi dua bagian. Sedangkan metode split-middle adalah kecendrungan arah grafik ditentukan berdasarkan nilai tengah (median) dari data point ordinalnya.

c. Menentukan kecendrungan kestabilitasan (trend stability)

Kecendrungan kestabilan dapat dihitung dengan langkah-langkah sebagai berikut:

1) Menentukan rentang stabilitas (trend stability) yaitu menggunakan kriteria stabilitas $15 \%$.

2) Menghintung nilai mean level yaitu semua skor dijumlahkan dan dibagi dengan banyak point data.

3) Menentukan batas atas yaitu dengan cara mean level $+1 / 2$ rentang stabilitas.

4) Menentukan batas bawah yaitu dengan cara mean level $-1 / 2$ rentang stabilitas.

5) Tentukan persentase stabilitas. Jika persentase stabilitas terletak antara 85\%-90\% maka kecendrungannya dikatakan stabil sedangkan jika dibawah persentase tersebut dikatakan tidak stabil.

d. Menentukan kecendrungan jejak data

Dalam menentukan kecendrungan jejak data hampir sama dengan arah kecendrungan yaitu dimasukkan hasil yang sama seperti kecendrungan arah, apakah data yang didapat meningkat (+), menurun (-) atau mendatar (=) dengan sumbu X.

e. Menentukan level stabilitas dan rentang 
1154 Efektivitas Model Pembelajaran Make A Match dalam Meningkatkan Kemampuan Membaca Permulaan bagi Anak Disleksia di Sekolah Dasar Penyelenggara Pendidikan Inklusif - Johandri Taufan, Ardisal, Konza Yola Konitah

DOI: https://doi.org/10.31004/basicedu.v4i4.521

Tingkat stabilitas (level stabilitas) menunjukkan derajat variasi atau besar kecilnya rentang pada kelompok data tertentu. Jika rentang datanya kecil atau tingkat variasinya rendah maka data dikatakan stabil, secara umum 85\%-90\% maka data dikatakan stabil sedangkan dibawah itu dikatakan tidak stabil. Untuk menentukan rentang dan tingkat stabilitas yaitu dengan cara menentukan rata-rata tingkat yang dilakukan dengan cara menjumlahkan nilai seluruh titik data dan membagi jumlahnya dengan jumlah titik data. Kemudian dengan menggunakan trend stability criterion envelope di sekitar ratarata (bagian atas dan bagian bawah).

f. Menentukan level perubahan

Menentukan tingkat perubahan atau level change yang menunjukkan berapa besar terjadinya perubahan data dalam suatu kondisi. Cara menghitungnya adalah :

1) Menentukan berapa besar data poin (skor) pertama dan terakhir dalam suatu kondisi

2) Kurangi data yang besar dengan data yang kecil

3) Tentukan apakah selilsihnya menunujukkan arah yang membaik atau memburuk sesuai dengan tujuan intervensi atau pengajaran

\section{Analisis Antar Kondisi}

Memulai menganalisa perubahan data antar kondisi, data yang stabil harus mendahului kondisi yang akan dianalisa karena jika data bervariasi (tidak stabil) maka akan mengalami kesulitan untuk menginterpretasi pengaruh intervensi terhadap variabel terikat. Di samping aspek stabilitas ada tidaknya pengaruh intervensi terhadap variabel terikat juga tergantung pada aspek perubahan level dan besar kecilnya overlap yang terjadi antar kondisi dapat dijelaskan antara lain sebagai berikut:

a. Menentukan jumlah variabel yang berubah Menentukan banyaknya variabel yang berubah yaitu dengan cara menentukan jumlah variabel berubah diantara kondisi baseline sebelum diberikan intervensi dan kondisi intervensi dengan menggunakan metode make a match.

b. Menentukan perubahan kecendrungan arah, dengan mengambil data pada analisis dalam kondisi yang berubah.

c. Menentukan perubahan kecendrungan stabilitas, dengan melihat kecendrungan stabilitas pada fase baseline sebelum diberikan intervensi (A1), fase intervensi (B) dan fase baseline setelah diberikan intervensi (A2) pada rangkuman analisis kondisi.

d. Menentukan level perubahan:

1) Tentukan data poin pada kondisi baseline sebelum diberikan intervensi (A) pada sesi terakhir dan sesi pertama pada intervensi (B).

2) Hitung selisih antar keduanya. 
1155 Efektivitas Model Pembelajaran Make A Match dalam Meningkatkan Kemampuan Membaca Permulaan bagi Anak Disleksia di Sekolah Dasar Penyelenggara Pendidikan Inklusif - Johandri Taufan, Ardisal, Konza Yola Konitah

DOI: https://doi.org/10.31004/basicedu.v4i4.521

3) Catat apakah perubahan tersebut membaik atau menurun. Jika tidak ada perubahan ditulis nol (0).

e. Menentukan overlap data kondisi baseline dan intervensi dengan cara:

1) Lihat kembali data pada kondisi baseline dan intervensi yang berada pada sebelum diberikan intervensi A1 dengan intervensi B yang berada pada rentang kondisi A1.

2) Kemudian lihat data pada kondisi baseline setelah tidak lagi diberikan intervensi A2 dengan intervensi B yang berada pada rentang kondisi A2.

3) Hitung berapa data poin pada kondisi intervensi B yang berada pada rentang kondisi A1 dan data poin pada kondisi intervensi (B) yang berada pada rentang A2.

4) Perolehan pada langkah nomor tiga dibagi dengan banyaknya data poin dalam kondisi intervensi (B) kemudian dikalikan 100. Itulah yang disebut dengan presentase overlap. Jika semakin kecil presentase overlap maka semakin baik pengaruh intervensi terhadap target behavior.

\section{HASIL DAN PEMBAHASAN}

Data hasil penelitian single subject research dianalisis dengan menggunakan analisis visual data grafik (Visual Analisis Of Grafik Data). Data yang diperoleh dari hasil pengamatan pada kondisi A1 (baseline sebelum diberikan intervensi), kondisi B (intervensi), dan pada kondisi A2 (baseline setelah tidak lagi diberi intervensi). Peneliti melakukan penelitian sebanyak 13 pertemuan dengan rincian empat kali pertemuan untuk kondisi baseline A1, sedangkan kondisi intervensi B dilakukan sebanyak lima kali pertemuan, kemudian empat kali pertemuan untuk kondisi baseline A2. Setiap pertemuan kondisi diukur dengan menghitung item yang benar dan menggunakan persentase.

Data pada kondisi ini diperoleh melalui pengamatan terhadap baseline (A1) yaitu 30, 30, 30, 30, kondisi intervensi (B) diperoleh data 80, 100, 100, 100 dan pada kondisi baseline (A2) diperoleh data $100,100,100,100$. Hal ini menunjukkan semakin meningkatkan persentase kemampuan membaca permulaan setelah diberikan perlakuan atau intervensi melalui metode pembelajaran Make A Match pada kondisi sebelumnya. Analisis data adalah tahap terakhir sebelum menarik kesimpulan. Dalam hal ini ada beberapa hal yang menjadi fokus peneliti, yaitu banyaknya data poin dalam setiap kondisi, banyak variabel terikat yang diubah, tingkat stabilitas dan perubahan level data dalam kondisi atau antar kondisi, arah perubahan dalam dan antar kondisi.

Pada analisis dalam kondisi berdasarkan grafik dapat dijelaskan bahwa panjang kondisi pada kondisi baseline (A1) sebanyak empat kali pengamatan dengan mean 30\%. Dari grafik terlihat bahwa batas atas pada kondisi baseline (A1) yakni $32.25 \%$ dan batas bawah $27.75 \%$. Estimasi kecenderungan arah menunjukkan bahwa pada kondisi baseline (A1) kecenderungan arahnya 
1156 Efektivitas Model Pembelajaran Make A Match dalam Meningkatkan Kemampuan Membaca Permulaan bagi Anak Disleksia di Sekolah Dasar Penyelenggara Pendidikan Inklusif - Johandri Taufan, Ardisal, Konza Yola Konitah

DOI: https://doi.org/10.31004/basicedu.v4i4.521

tetap dan masih sangat rendah. Untuk kecendrungan stabilitas pada kondisi baseline (A1) menunjukkan hasil yang stabil, karena persentase stabilitas kondisi baseline (A1) adalah 100\%. Kecenderungan jejak data pada kondisi baseline adalah tetap namun masih rendah. Data kecenderungan stabilitas baseline (A1) datanya stabil terletak pada rentang 30\%-30\%. Dapat dipaparkan bahwa level perubahan pada kondisi baseline (A1) pada pengamatan hari pertama dan kedua adalah 30\% dan tiga hari terakhir $30 \%$. Kemudian dari nilai pengamatan awal dan akhir tersebut nilai yang paling tinggi dikurangi nilai yang paling rendah yaitu $30 \%-30 \%=0 \%$. Maka ini berarti pada kondisi baseline (A1) level perubahannya adalah tetap $(=)$ namun sangat rendah.

Pada kondisi intervensi (B) panjang kondisi pada kondisi intervensi (B) adalah sebanyak lima kali pengamatan. Mean pada kondisi intervensi (B) yang terletak pada angka 96\%. Batas atasnya adalah $103.5 \%$ dan batas bawahnya $88.5 \%$. Estimasi kecendrungan arah menunjukkan arah yang meningkat dan kecendrungan stabilitas adalah tidak stabil dengan persentase stabilitas menunjukkan $80 \%$. Untuk menjelaskan kecendrungan jejak data pada kondisi intervensi (B) adalah meningkat. Menentukan level stabilitas dan rentang datanya menunjukkan ketidakstabilan dengan rentang 80\%-100\%. Selanjutnya dapat dilihat pada grafik bahwa level perubahan pada kondisi intervensi (B) yang memiliki jumlah data sebanyak lima, data awal setelah diberikan perlakuan adalah $80 \%$ dan data akhirnya setelah diberikan perlakuan adalah $100 \%$. Nilai tertinggi dikurangi nilai terendah $100 \%-80 \%=20 \%$, hal ini berarti level perubahan pada intervensi semakin meningkat $(+)$.

Selanjutnya pada kondisi baseline (A2) dapat kita lihat pada grafik di atas panjang kondisinya adalah empat kali pertemuan dengan mean $100 \%$, batas atas $107.5 \%$ dan batas bawah adalah 92.5\%. Pada Tabel 1. dapat diamati bahwa estimasi kecenderungan arah pada kondisi baseline (A2) adalah mendatar. Selanjutnya pada kondisi baseline (A2) kecendrungan stabilitasnya adalah stabil dengan persentase stabilitas $100 \%$. Untuk menentukan kecenderungan jejak data sama dengan menentukan kecenderungan arah. Kecenderungan jejak data pada kondisi baseline (A2) adalah tetap. Data kecenderungan stabilitas datanya stabil. Adapun variabel kemampuan anak disleksia dalam membaca permulaan (kata benda) terletak pada rentang 100\%-100\%. Data pada kondisi A2 persentase terendahnya 100\%, persentase tertingginya $100 \%$. Pada kondisi baseline (A2) level perubahannya 100\%-100\% $=0 \%$ ini berarti tetap.

Selanjutnya analisis antar kondisi berdasarkan grafik terlihat bahwa jumlah variabel yang diubah dalam penelitian ini adalah satu variabel terikat yaitu kemampuan membaca permulaan. Perubahan kecenderungan arah kemampuan anak dalam membaca permulaan selama kondisi A1 arahnya tetap (=) namun sangat rendah, sedangkan pada kecenderungan arah pada kondisi B kemampuan anak dalam membaca permulaan meningkat (+) Dan pada kondisi A2 
1157 Efektivitas Model Pembelajaran Make A Match dalam Meningkatkan Kemampuan Membaca Permulaan bagi Anak Disleksia di Sekolah Dasar Penyelenggara Pendidikan Inklusif - Johandri Taufan, Ardisal, Konza Yola Konitah

DOI: https://doi.org/10.31004/basicedu.v4i4.521

kecenderungan arahnya juga tetap (=). Adapun level perubahan kemampuan anak dalam melakukan membaca permulaan (kata benda) dari kondisi baseline sebelum diberikan intervensi (A1) sampai kepada kondisi awal intervensi ada peningkatan yaitu 50\% dan pada kemampuan anak dalam melakukan membaca permulaan (kata benda) dari kondisi saat diberikan intervensi (B) sampai kepada kondisi setelah anak tidak lagi diberikan intervensi (A2) datanya meningkat sebanyak 20\%. Dan overlape pada pada penelitian ini yang semakin mengecil. Selanjutnya analisis antar kondisi berdasarkan grafik terlihat bahwa jumlah variabel yang diubah dalam penelitian ini adalah satu variabel terikat yaitu kemampuan membaca permulaan. Perubahan kecenderungan arah kemampuan anak dalam membaca permulaan (kata benda) selama kondisi A1 arahnya tetap (=) namun sangat rendah, sedangkan pada kecenderungan arah pada kondisi B kemampuan anak dalam membaca permulaan meningkat (+) Dan pada kondisi A2 kecenderungan arahnya juga tetap (=).

Adapun level perubahan kemampuan anak dalam membaca permulaan dari kondisi baseline sebelum diberikan intervensi (A1) sampai kepada kondisi awal intervensi ada peningkatan yaitu 50 $\%$ dan pada kemampuan anak dalam membaca permulaan dari kondisi saat diberikan intervensi (B) sampai kepada kondisi setelah anak tidak lagi diberikan intervensi (A2) datanya meningkat sebanyak 20\%. Dan overlape pada pada penelitian ini yang semakin mengecil.
Tabel. Analisis dalam Kondisi Kemampuan Membaca Permulaan

\begin{tabular}{cccc}
\hline Kondisi & A1 & B & A2 \\
\hline $\begin{array}{c}\text { Panjang } \\
\text { kondisi }\end{array}$ & 4 & 5 & 4 \\
$\begin{array}{c}\text { Estimasi } \\
\text { kecendrungan } \\
\text { Arah }\end{array}$ & $(=)$ & $(+)$ & $(=)$ \\
$\begin{array}{c}\text { Kecendrungan } \\
\text { stabilitas }\end{array}$ & $\begin{array}{c}100 \% \\
(\text { stabil) }\end{array}$ & $\begin{array}{c}80 \% \\
\text { (tidak } \\
\text { stabil) }\end{array}$ & $\begin{array}{c}100 \% \\
\text { (stabil) }\end{array}$ \\
Jejak data & $(=)$ & $(+)$ & $(=)$ \\
\hline
\end{tabular}

Dari hasil penelitian data terbukti bahwa metode make a match efektif untuk meningkatkan kemampuan dalam membaca permulaan (kata benda) pada anak disleksia. Hal ini terbukti dari hasil grafik data yaitu kecenderungan kondisi (A) banyaknya jumlah kata yang mampu dibaca anak stabil (=) kemudian pada kondisi (B) intervensi arah kecenderungan jumlah kata yang mampu dibaca anak naik (+) dan bervariasi. Lalu pada kondisi (A2) banyaknya jumlah kata yang mampu dibaca anak stabil (=).

Kemampuan membaca anak yang dapat dilihat berdasarkan intervensi yang telah dilakukan oleh anak melalui metode yang sesuai dengan kondisi anak. Pada penelitian ini menggunakan metode pembelajaran make a match dalam meningkatkan kemampuan membaca permulaan, khususnya lagi pada membaca kata benda. Metode make a match menurut (Rusman, 2012) penerapan metode ini dimulai dengan teknik, yaitu "siswa disuruh mencari pasangan kartu yang merupakan jawaban/soal sebelum batas waktunya, siswa yang dapat mencocokkan kartunya diberi poin". 
1158 Efektivitas Model Pembelajaran Make A Match dalam Meningkatkan Kemampuan Membaca Permulaan bagi Anak Disleksia di Sekolah Dasar Penyelenggara Pendidikan Inklusif - Johandri Taufan, Ardisal, Konza Yola Konitah

DOI: https://doi.org/10.31004/basicedu.v4i4.521

Hasil penelitian ini menunjukkan bahwa pada kondisi awal (baseline 1) kemampuan anak dalam membaca permulaan khususnya membaca kata-kata benda sedikit sekali yaitu tiga kata dari sepuluh kata yang ada. Hal ini terlihat dari hasil pengamatan yang dilakukan sebanyak empat kali yaitu pada hari pertama pengamatan anak hanya bisa membaca tiga kata benda dengan benar. Kemudian pada pertemuan kedua, ketiga dan keempat anak tetap hanya mampu membaca tiga kata dari sepuluh kata yang disediakan dengan benar, bearti kemampuan membaca anak pada kondisi baseline (A) rendah.

Kemudian pada kondisi (B) intervensi kemampuan anak dalam membaca yang dilakukan sebanyak lima kali pertemuan menjadi meningkat dari tiga kata menjadi delapan kata. Lalu pada pertemuan selanjutnya anak mampu membaca sepuluh kata dari sepuluh kata yang disediakan. Maka terbukti bahwa dengan menggunakan metode pembelajaran make a match dapat meningkatkan kemampuan membaca permulaan pada anak disleksia dengan demikian hipotesis penelitian ini diterima. Artinya metode pembelajaran make a match dapat meningkatkan kemampuan membaca permulaan anak disleksia di sekolah dasar. Kemudian pada kondisi baseline (A2) kemampuan anak dalam membaca permulaan khususnya membaca kata-kata benda stabil. Anak mampu membaca kata benda sepuluh dari sepuluh kata yang disediakan.

Hal ini terbukti setelah data diatas dianalisis menggunakan garis grafik yang telah dibuat berdasarkan pengolahan data yang diperoleh, menunjukkan bahwa metode pembelajaran make a match dapat meningkatkan kemampuan membaca permulaaan pada anak disleksia di sekolah dasar kelas 2. Namun demikian hasil penelitian ini tidak lepas dari kekurangan-kekurangan yang disebabkan oleh ketebatasan peneliti.

\section{KESIMPULAN}

Dari hasil penelitian yang telah dilakukan di salah satu sekolah dasar penyelenggara pendidikan inklusif, serta telah dijelaskan dalam pemaparan data penelitian yang memiliki tujuan untuk meningkatkan kemampuan membaca permulaan pada anak disleksia melalui metode pembelajaran make a match terlihat bahwa kemampuan membaca permulaan meningkat. Setelah penelitian dilaksanakan sebanyak 13 kali pertemuan meningkat, dengan tiga kondisi, pada baseline (A1) sebanyak empat kali pertemuan, pada kondisi intervensi (B) sebanyak lima kali pertemuan dan pada kondisi baseline (A2) empat kali pertemuan, menunjukan hasil bahwa kemampuan membaca permulaan bagi anak disleksia dapat meningkat. Bearti telah diperoleh bukti yang cukup untuk menyatakan bahwa kemampuan membaca permulaan bagi anak disleksia dapat meningkat melalui metode pembelajaran make a match.

Hasil analisis data, baik analisis dalam kondisi maupun analisis antar kondisi menunjukkan estimasi kecenderungan arah, kecenderungan kestabilan, jejak data tingkat perubahan yang meningkat secara positif dan overlape yang semakin kecil. Dari keseluruhan analisis data baik dalam kondisi maupun antar 
1159 Efektivitas Model Pembelajaran Make A Match dalam Meningkatkan Kemampuan Membaca Permulaan bagi Anak Disleksia di Sekolah Dasar Penyelenggara Pendidikan Inklusif - Johandri Taufan, Ardisal, Konza Yola Konitah

DOI: https://doi.org/10.31004/basicedu.v4i4.521

kondisi menunjukkan adanya perubahan kemampuan membaca permulaan anak disleksia kearah yag lebih baik. Hasil perolehan data ini menunjukkan bahwa metode yang pemberian tugas dan ceramah saja, sebaiknya gunakan metode yang membuat anak meras nyaman, menyenangkan dan membuat anak aktif dalam pembelajarannya.

\section{DAFTAR PUSTAKA}

Dalman. (2014). Keterampilan Membaca. Jakarta: Rajawali Pers.

Deschuri, C., Kurnia, D., \& Gusrayani, D. (2016). Penerapan Model Kooperatif Teknik Make a Match Dengan Media Kartu Klop Untuk Meningkatkan Hasil Belajar Siswa. Penerapan Model Kooperatif Teknik Make a Match Dengan Media Kartu Klop Untuk Meningkatkan Hasil Belajar Siswa, 1(1), 361-370.

https://doi.org/10.23819/pi.v1i1.3042

Djamarah, \& Bahri, S. (2008). Rahasia Sukses Belajar. Jakarta: Rineka Cipta.

Fatimah, I. D. (2017). Penerapan Model Pembelajaran Make a Match dengan Media Kartu Bergambar untuk Meningkatkan Motivasi dan Hasil Belajar Siswa. Ilmu Pendidikan: Jurnal Kajian Teori Dan Praktik Kependidikan, 2(1), 28-37. https://doi.org/10.17977/um027v2i12017p02 8

Jamaris, M. (2009). Kesulitan Belajar Perspektif Asessmen dan Penanggulangannya. Jakarta: Yayasana Penamas Murni.

Nurhidayah, R. S., Kurnia, D., \& Sudin, A. (2017). PENERAPAN MODEL PEMBELAJARAN KOOPERATIF TIPE MAKE A MATCH UNTUK MENINGKATKAN HASIL BELAJAR SISWA PADA MATERI KERAGAMAN SUKU BANGSA DAN BUDAYA. Jurnal Pena Ilmiah, 2(1), 20512060.

https://doi.org/https://doi.org/10.23819/pi.v2i 1

Pathanah, Y. (2015). Efektifitas Teknik Make A
Match Untuk Meningkatkan Kemampuan Bahasa Inggris Anak Hambatan Pendengaran Kelas VII di SMPN 23 Padang. Jurnal Ilmiah Pendidikan Khusus, 4(3), 658-669.

Rusman. (2012). Model-model Pembelajaran Mengembangkan Profesionalisme Guru. Jakarta: Rajawali Pers.

Sunanto, J. (2005). Pengantar Penelitian Dengan Subyek Tunggal. University of Tsukuba: Criced. 